\title{
Determinants of Vietnamese Listed Firm Performance: Competition, Wage, CEO, Firm Size, Age, and International Trade
}

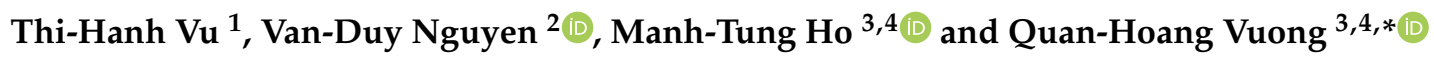 \\ 1 School of Economics and International Business, Foreign Trade University, 91 Chua Lang Street, \\ Dong Da District, Hanoi 100000, Vietnam; hanhvt@ftu.edu.vn \\ 2 Quantitative Analysis Center, QA Global Co., 9/82 Chua Lang street, Dong Da District, Hanoi 100000, \\ Vietnam; duynguyen.qa@gmail.com \\ 3 Center for Interdisciplinary Social Research, Phenikaa University, Yen Nghia, Ha Dong District, \\ Hanoi 100803, Vietnam; tung.homanh@phenikaa-uni.edu.vn \\ 4 Faculty of Economics and Finance, Phenikaa University, Yen Nghia, Ha Dong District, \\ Hanoi 100803, Vietnam \\ * Correspondence: hoang.vuongquan@phenikaa-uni.edu.vn
}

Received: 17 March 2019; Accepted: 9 April 2019; Published: 11 April 2019

check for updates

\begin{abstract}
This study investigates the relationship between firms' competition, wage, CEOs' characteristics, and firm performance (measured by net income per employee, return on assets (ROA) and return on equity (ROE)) of Vietnam's 693 listed firms in 2015 using both the ordinary-least-square (OLS) and quantile regression methods. Triangulating the results coming from the analysis of three different measures of firm performance, this study consistently confirms that the sex of CEOs and chairman turns out to be insignificant in explaining firm performance and there is a negative association between capital intensity and firm performance. For financial firms, the age of a firm and average wage per employee are negatively associated with all types of firm performance. The quantile regression method shows that the age of a firm is negatively correlated with its net income per employee for small firms, while it is insignificant for medium-sized firms. Meanwhile, firm size is positively associated with firm performance. These results indicate Vietnam's business activities are still concentrating on low labor cost, labor intensive, and low-tech production, thus, policies that promote innovation and high-tech applications should be encouraged.
\end{abstract}

Keywords: competition; wage; net income per employee; firm performance; productivity; Vietnam; listed company

\section{Introduction}

In the age of rapid digitization and globalization, companies worldwide are facing increasing pressure to innovate, increase productivity, and increase competitiveness. While this emerging trend is clearer than ever when looking at the rise of "computational entrepreneurship" in developed countries, what remains elusive is whether this is the case in developing countries (Vuong 2019a). In order to foster a more technologically advanced entrepreneurship, it is first and foremost necessary to go back to the micro level and examine the factors that affect firm performance, whether high- or low-tech. Understanding firm performance requires a thorough grasp of a firm's characteristics and its entrepreneurial endeavors. The current research looks at the transitional economy of Vietnam whose emerging market characteristics have captured the interests of academics over the past decades. Through an investigation of the performance of nearly 700 listed companies on Vietnam's stock markets, this study will triangulate the empirical results of three different indicators of a firm's performance: 
net income per employee, return on assets (ROA), and return on equity (ROE). It is hoped that robust evidence on the correlates of firm performance can be found. As such, the current study not only adds to the related literature on the issue, but also highlights, once again, a gap in the application of technology among public companies in Vietnam. The next subsections will review the relevant studies that have been done all over the world and in Vietnam to call attention to the scanty empirical evidence coming from the emerging market of nearly 100 million people with the Gross Domestic Products (GDP) at USD 204 billion in 2015 and a growth rate over 6\% since then (Vuong 2019b).

\subsection{Studies on the Correlates of Firm Performance around the World}

Given the importance of explaining firm performance, a large volume of research in this area has focused on uncovering various factors associated with firm performance. Considering the effect of female leadership, there is more evidence for the positive impact of having a female in the top position of a company on their performance. Dezsö and Ross (2012) analyzed 15 years of panel data from the S\&P 1500 firm and found having a female in top management does improve firm performance, given that innovation is the focus of a firm's strategy. Dezsö and Ross used Tobin's $Q$ as the primary measure of firm performance. In a similar vein, Lückerath-Rovers (2013) found that companies with women on board are performing better than those without through analyzing 99 listed firms in the Dutch Female Board Index. Using different measures of performance, such as return on assets (ROA), other studies found a positive correlation between having female in the board of directors and performance (Carter et al. 2003; Krishnan and Park 2005). In contrast, in a Danish study, Rose (2007) did not find any significant relationship. This inconsistency might be explained by the sampling methods or cultural factors or even study designs. In many cases, it is a not a straightforward link between having women directors and better performance. For example, a study in China investigated this question among China's listed firms from 1999 to 2011 and found the type of ownership can be a mitigating factor: state-controlled firms are less likely to benefit from having female leaders (Liu et al. 2014).

Regarding competition as a correlate of firm performance, Schiffbauer and Ospina (2006) attempted to measure a firm's productivity in four different ways, among which the total factor productivity (TFP) is employed under an augmented Cobb-Douglas production function. They found that in countries that reformed during 2004, firms experienced a more pronounced increase in competition and in turn, productivity. Pressure from international competition can also exert positive influence, greater international competition enlarges the relevant market and can affect both the number and the type of competitors a firm faces (De Loecker and Biesebroeck 2018). Regarding competition effects across product markets, high rent firms (firms that are able to earn profits beyond a competitive level) had consistently lower productivity growth than low rent firms (Nickell 1996). More recently, Bourlès et al. (2013) considered the impact of competition in intermediate goods markets on downstream productivity. Notably, their evidence shows that anticompetitive upstream regulations have significantly curbed TFP growth, particularly for firms that are close to the productivity frontier.

In 2012, Wager surveyed the literature on international trade and firm performance attempting to establish the links between exports and imports activities and various dimensions of firm performance (productivity, wages, profitability, and survival). Wagner found that a large amount of empirical studies in various countries points to the same direction: international training firms perform better in terms of productivity than nonexporters and nonimporters. However, this trend must be interpreted with caution due to the absence of comparable sample size (Wagner 2012). Andersson et al. (2012) presented an analysis of international trade engagement of Swedish firms, showing the relationship between firm performance and international trade is not straightforwardly about a firm being an exporter or nonexporter; the geographical nature of export and import activities also has a statistically significant effect on firm's productivity. In a study on Portuguese manufacturing firms, two-ways traders are shown to perform better than only exporters or only importers. Moreover, intensity of international training activities, diversity of market goods, and destination of products are also explanatory for 
better performance (Silva et al. 2013). A study in 2018 suggests the gain in firm performance is three times higher than the direct costs of export promotion (Munch and Schaur 2018).

Considering the relationship of wage and firm performance, an empirical study using a dataset of 200,000 French firms between 1995 to 2007 found that firm size regulation seems to result in a loss in productivity as many productive firms choose to stay below the threshold of firm size to avoid regulation. These productive firms are allocated too little employment and must bear implicit labor tax; the reducing equilibrium wages encourages more people who work as small entrepreneurs rather than working as employees for more productive firms (Garicano et al. 2016). Regarding firm size, empirical studies on corporate finance have commonly used firm size as an important and a fundamental firm characteristic. This factor is worth considering given that business regulations or taxation policies often differ among big, medium, and small firms, which would in turn affect the firm's performance (Garicano et al. 2016, 2017). Additionally, firm size is empirically found to have positive association with capital structure, such that bigger firms may have higher leverage in external financing (Kurshev and Strebulaev 2015). On the relationship between firm size and firm performance, studies have sought to compare the level of competitiveness or corporate social performance between small and big firms. For instance, Wolff and Pett (2000) noted that when it comes to the internationalization of small U.S. firms, the larger ones did show competitive patterns consistent with their size-related resource base, as opposed to the smaller ones. Meanwhile, scholars have confirmed the positive correlation of corporate social performance and financial performance in firms with a large size (Orlitzky 2001; Schreck and Raithel 2015). In terms of sustainability performance, small and medium enterprises, particularly in the food supply chain, are found to be more susceptible to high social, environmental, and economic pressures than larger enterprises. In one study in Turkey, the researchers found a positive correlation between the size indicators of a firm and its performance (Doğan 2013).

Researchers have also tried to uncover other factors that can influence firm performance. Sun and Yu (2015), for example, found a positive correlation between performance (measured by sales per employees and net income per employee) and Corporate Social Responsibility (CSR) practices and firms without. Choudhary (2014) looked at the impact of smartphones use on net income per employee and found they have a positive correlation. Camisón and Villar-López (2014) analyzed a dataset of 144 Spanish firms and found that organizational innovation does have a positive effect on technological capabilities, which in turn tends to cause better firm performance. A study on 89 high-tech firms in Jiangsu province, China revealed that knowledge sharing, whether explicit or implicit, does support innovation and performance (Wang and Wang 2012). A study in Tunisia looked at the relationship between information and communication technologies (ICTs) use and the performance of Tunisian SMEs (measured by net profit margins) and showed there is a significant association between the level of ICT use and firm performance (Piget and Kossaï 2013). The research area where correlates of firm performance are studied does fall into the larger context of understanding corporate governance. Interesting studies have been carried out, for example, on market competition (Giroud and Mueller 2011), CEO tournament as governance (Coles et al. 2017), compensation incentives (Core and Guay 1999), or mutual monitoring of executives (Li 2014) as governance mechanisms.

As shown above, although the literature on firm performance around the world is truly diverse, the same cannot be said about business research in Vietnam, an emerging economy which has only entered the lower middle income rank recently (Vuong 2019b). The next section will cover the meager ground of research on firm performance in Vietnam.

\subsection{Studies on Firm Performance in Vietnam}

In the recent years, Vietnam's now nearly 100 million people has been enjoying continuous economic growth for over 30 years, in this success, entrepreneurship and internationalization of the economy have played a crucial role. The state-led economic reform in 1896 has brought radical changes to the country; the country's GDP per capita has reached to nearly US $\$ 2300$ in 2015 from only US $\$ 217$ in 1989 (Vuong 2019b). It is estimated that in just 8 years from 1991 to 1999, there were around 40,000 
newly established companies (Pham and Vuong 2009). Following this first generation of business ventures, the number of small and medium sized enterprises (SMEs) continued to increase from 349,000 in 2009 (Vuong and Tran 2009) to around 500,000 in 2017 (Nhan Dan 2017). In 2015, Vietnam was considered one of the most globalized populous economies in the world (Kopf 2018).

Recently, the arrival of Industry 4.0 has marked a new era for entrepreneurship in Vietnam (Vuong et al. 2019), the next generation of business ventures is now operating ever more on complex computational platforms, marking a shift to a new form of entrepreneurship: computational entrepreneurship (Vuong 2019a). In 2017, it is reported that Vietnam is among the countries with the highest total early-stage entrepreneurial activity-23.3\% - and a significant entrepreneurial spirit index-0.26 (GERA 2018). Some of the successful startups are digital, such as Foody-a food delivery app, or Tiki-an e-commerce website, or WeFit-a fitness app allowing users to use gyms around a city.

Given the importance of successful entrepreneurship for Vietnam, it goes without saying understanding which factors influence firm performance is crucial. However, research in this area remains meager and scattered over the years, especially when it comes to listed companies. A comparative study between Thai and Vietnamese SMEs in 2003, found the difference in entrepreneurial orientation between Thai and Vietnamese business owners lead to difference in firm performance. Thai SMEs are more innovative and proactive, while Vietnamese SMEs are likely to take risks. Thai SMEs have higher perceived business growth, job creation, and net profit than Vietnamese SMEs (Swierczek and Ha 2003). Another study examined the impact of privatization by comparing the preand postprivatization financial and operating performance of 121 former state-owned enterprises (SOEs) (Truong et al. 2006). The results highlighted significant hikes in profitability, revenues, efficiency and employee income, in addition to confirming the key determinants of better performance to be firm size, residual state ownership, corporate governance, and stock listing (Truong et al. 2006).

More recent studies also noted that when ownership is concentrated, firms with residual state ownership see poorer performance than those with foreign ownership (Phung and Hoang 2013; Phung and Mishra 2016; Tran et al. 2014). These findings, however, are contested as another research that used data of listed firms in Vietnam reached the opposite conclusion-that foreign ownership turns out to have a negative impact on firm performance but positive impact on capital structure (Phung and Le 2013). Moreover, in a resource-constrained setting such as Vietnam, Vuong (2016a) shed light on the significant relationships between operational scales, financial resources and firms' performance, all the while highlighting the importance of an innovation strategy, as opposed to factors such as firm size, sales, and growth rate to Return-on-equity (ROE).

In a different approach on evaluating firm performance, Vo and Nguyen (2014) looked at a set of variables related to corporate governance. Particularly, upon analyzing a dataset of 177 listed Vietnamese companies from 2008-2012, the authors found that duality role of CEO and board independenance are positively correlated with firm performance. However, there was no empirical support for a relationship between board size and firm performance (Vo and Nguyen 2014). Additional studies have even noted a positive association between a firm's long-term credit financing relationship with banks and firm performance (Thanh and Ha 2013), a significantly negative relation between firm's debt ratio and its performance (Le and Phan 2017), a positive correlation between corporate social responsibility disclosures and firm value (Nguyen et al. 2015), and a significant and positive relationship between board diversity and earnings quality (Hoang et al. 2017), to name a few.

Overall, it is clear that there are a wide range of approaches in studying factors that are associated with firm performance in Vietnam. Most research articles in this area tend to focus on capital structure, board diversity, and ownership. Another striking issue is that measure of firm performance in Vietnam appears to vary greatly, which is also an issue for research studies around the world. For example, Vu et al. (2016) used Return on Assets (ROA), Swierczek and Ha (2003) used net profit, and Vo and Nguyen (2014) used four measures (ROA), return on equity (ROE), Z-score and Tobin's Q. It appears that firm performance measured using net income per employee has not been deployed in Vietnam. This paper will focus on this understudied area of the literature by analyzing the association between 
net income per employee and predictor variables such as firms' wage, competition, age, and CEO's sex. Analyzing pure cross-sectional data of 693 firms which are listed via the Ho Chi Minh City Stock Exchange (HOSE) and Hanoi Stock Exchange (HNX) indices using both OLS and quantile regression methods, this study will triangulate the empirical results coming from analyzing the correlates of three indicators of firm performance: net income per employee, ROA, and ROE.

\section{Materials and Methods}

\subsection{Data and Variables}

This study started in 2016, at the time, 2015 was the latest year for which data on listed Vietnamese firms were published. Hence, data on these firms in 2015 were obtained from FiinPro (StoxPlus), which provides an extensive range of comprehensive financial information covering Vietnam's market, including around 800 listed firms and 1200 public unlisted firms. The database includes 693 firms operating in different sectors (Industry Division ICB 5), which include IT, industry, service consumption, petroleum, pharmaceuticals and health service, consumer goods, banking, materials, finance, and public utility sectors. All firms in our sample are listed on HNX and HOSE of Vietnam. The data were processed with Stata 14.0. Summary statistics of all variables used in the regression are provided in Table 1.

Table 1. Descriptive statistics of the dataset.

\begin{tabular}{ccccccc}
\hline Variable Name & $\begin{array}{c}\text { Variable } \\
\text { Code }\end{array}$ & Mean & $\begin{array}{c}\text { Standard } \\
\text { Deviation }\end{array}$ & Min & Max & Observations \\
\hline $\begin{array}{c}\text { Dependent variable: Firm } \\
\text { performance }\end{array}$ & $\begin{array}{c}\text { "Firm } \\
\text { performance" }\end{array}$ & & & & & \\
\hline Net income per employee & "NIE" & 21.1 & 1.23 & 14.06 & 25.51 & 639 \\
\hline ROA & "ROA" & 0.064 & 0.081 & -0.292 & 0.839 & 653 \\
\hline ROE & "ROE" & 0.121 & 0.146053 & -0.9993 & 1.4907 & 653 \\
\hline Explanatory variable: & & & & & & 6.74 \\
\hline Competition & "COP" & 0.12 & 0.42 & 0 & 0.74 & 693 \\
\hline Wage & "Wage" & 0.1 & 0.1 & 0 & 2.49 & 672 \\
\hline Sex of CEO (dummy) & "Sex" & 1.92 & 0.2 & 0 & 1 & 689 \\
\hline Age & & 5.75 & 3.02 & 0 & 15 & 693 \\
\hline Capital intensity & "CapIntensity" & 0.36 & 0.66 & 0 & 6.84 & 672 \\
\hline Size & "Size" & 27.2 & 1.64 & 23.28 & 34.37 & 690 \\
\hline Total number of employees & "SizeEmp" & & & & \\
\hline International trade (dummy) & "InterTrade" & 0.21 & 0.4 & 0 & 1 & 690 \\
\hline
\end{tabular}

Regarding the dependent variable, this study follows the literature on measuring firm-level employee performance by dividing a firm's net income over its total number of employees, which takes the form of natural logarithm (Brandt et al. 2012; Choudhary 2014; Davis and Daley 2008; Sun and Yu 2015). This measure is sometimes referred to as a measure of firm-level productivity, which falls into the broader consideration of firm performance (Boardman et al. 2013; Davis and Daley 2008; Zhang and Xia 2013). Besides considering this unconventional indicator of firm performance, other conventional indicators, such as ROE and ROA, will also be examined.

For the explanatory variables, the Competition variable is constructed by dividing a firm's income over the total income of 693 firms in 2015. Competition variable varies from 0 to 0.74 with a mean value of 0.12 and standard deviation is 0.4 . The wage of a firm measures the average labor cost over its total number of employees. In fact, wage per employee is a better measure because employees are heterogeneous factors across sectors. Characteristics of a firm's CEO, specifically the CEO's sex, is also taken into account. Studies such as Brennan and McCafferty (1997) suggest that female executives 
may have a better understanding of consumer behavior and customers' needs, which may create a competitive advantage for female-controlled firms. The age of a firm is the number of years since a firm was first listed. The capital intensity variable is measured by dividing the net fixed assets of a firm by its number of employees. This may also provide information on whether a firm is more labor-intensive or is more invested in technology. In this study, firm size is measured by the total number of employees.

\subsection{Methods: OLS and Quantile Regression}

The regression model follows the OLS method and takes the form of:

$$
\begin{aligned}
\text { Firm performance }_{i} & =\alpha_{0}+\beta_{1} \text { Competition }_{i}+\beta_{2} \text { Wage }_{i}+\beta_{3} \text { Sex }_{i}+\beta_{4} \text { Age }_{i} \\
& +\beta_{5} \text { CapIntesity }_{i}+\beta_{6} \text { Size }_{i}+\beta_{7} \text { InterTrade }_{i}+\mu_{i}
\end{aligned}
$$

In the model, subscript $i$ denotes firm $i$ and $\mu_{i}$ is the error term (see Figure 1).

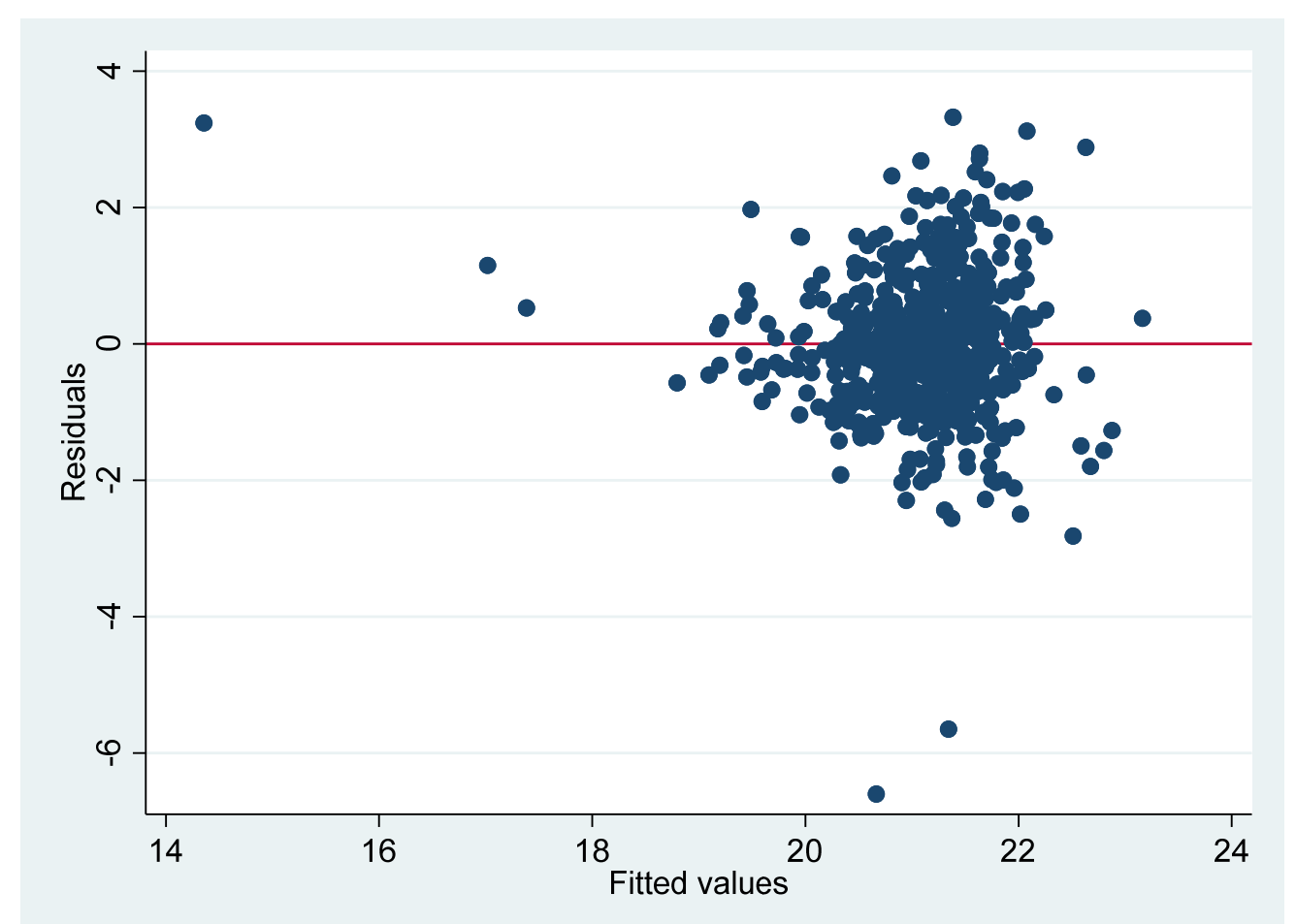

Figure 1. Firm performance varies across industries. The $Y$ axis in the graph plots residuals obtained by regressing firm performance with variables in the right-hand side. The $X$ axis plots firm performance (net income per employee).

Besides the OLS method, the quantile regression method has also been deployed. As the dataset contains a significant number of extreme values especially firms are heterogeneous in terms of capital commutation, the OLS method may not yield efficient estimators due to the linear model between a set of regressors and the outcome variable is based on the conditional mean function $E(y \mid x)$. We are therefore interested in obtaining regression coefficients for the relationship between the regressors and the dependent variable by using the conditional median function $Q_{q}(y \mid x)$. While estimators obtained from OLS based on minimizing the total sum of squared error $\left(\sum_{i} \varepsilon_{i}^{2}\right)$, the quantile regression method known as least-absolute-deviations (LAD) developed by Honoré (1992) minimizes $\sum_{i}\left|\varepsilon_{i}\right|$. More importantly, quantile regression is a better alternative method if the errors are highly non-normal. This method, providing a richer characterization of the data, allows us to entangle the impact of a covariate on the entire distribution of the response variable rather than its conditional mean (Baum 2013). 


\section{Results}

\subsection{Based Regression Results for the Correlates of Net Income per Employee}

First, as endogeneity among the variables is a major obstacle in understanding the relationship among the variables in empirical studies on firm performance (Li 2016), this study tested the endogeneity problem by checking the correlation among the independent variables. The results of the correlation matrix are shown in Table 2 below, and it is notable that there is no strong correlation among all the independent variables.

Table 2. Correlation matrix of the independent variables.

\begin{tabular}{lllllll}
\hline & COP & Wage & Sex & Age & CapIntensity & SizeEmp \\
\hline COP & 1 & & & & \\
Wage & -0.0707 & 1 & & & \\
Sex & -0.0658 & 0.0125 & 1 & & & \\
Age & 0.0375 & $0.1019 *$ & -0.0241 & 1 & & \\
CapIntensity & -0.0327 & 0.0203 & 0.0302 & -0.0366 & 1 & \\
SizeEmp & $0.3419 *$ & $-0.298 *$ & 0.0508 & $0.0776 *$ & $0.1517 *$ & 1 \\
\hline \multicolumn{7}{c}{$* 0.1$ (statistically significant at the conventional $10 \%$ level). }
\end{tabular}

Next, the regression is performed for small and medium sized firms to evaluate how these two factors affect firms' performance differently. In general, the signs of all coefficients across models are consistent, although their magnitudes, in some cases, show considerable differences. It should be noted that all standard errors of coefficients have been adjusted for robustness. Firm's heterogeneity among sectors is also controlled for in the column S\&M (stands for Small and Medium) of Table 3.

Table 3. Regression results for small and medium sized firms.

\begin{tabular}{cccc}
\hline Variable & Small & Medium & S\&M \\
\hline "COP" & $5.712^{* * *}$ & $0.362^{* * * *}$ & 0.005 \\
& $(0.879)$ & $(0.0787)$ & $(0.63)$ \\
"Wage" & $-2.479^{* * *}$ & $-4.359^{* * *}$ & $-2.69^{* * *}$ \\
& $(0.355)$ & $(0.373)$ & $(-10.65)$ \\
"Sex" & 0.232 & -0.125 & -0.02 \\
& $(0.339)$ & $(0.160)$ & $(-0.15)$ \\
"Age" & $-0.0892^{* * *}$ & -0.0120 & $-0.05^{* * *}$ \\
& $(0.0276)$ & $(0.0147)$ & $(-3.35)$ \\
"CapIntensity" & -0.0878 & $-0.307^{* * *}$ & $-0.32^{* * *}$ \\
& $(0.0842)$ & $(0.0967)$ & $(-4.85)$ \\
"SizeEmp" & & & 0.24 \\
& & & $(7.10)$ \\
"InterTrade" & 0.376 & -0.0338 & -0.10 \\
& $(0.258)$ & $(0.0976)$ & $(-0.85)$ \\
Constant & $21.46^{* * *}$ & $21.74^{* * *}$ & $15.71^{* * *}$ \\
& $(0.664)$ & $(0.337)$ & $(0.941)$ \\
Observations & 254 & 383 & 611 \\
R-squared & 0.33 & 0.34 & 0.30 \\
\hline
\end{tabular}

Notes: ${ }^{* * *}$ significant at $1 \%$. Absolute $t$-statistics are in parentheses.

In line with the existing literature, the higher the level of firms' competition, the higher their net income per employee denoting that when firms are able to gain more their market share, they are motivated to increase their productivity.

The wage cost of firms negatively affects the net income per employee of both small and medium sized firms with a $1 \%$ level of significance $\left(\beta_{2}\right.$ equals -2.479 and -4.359 respectively, $p$-value $\left.<0.01\right)$, implying that highly skilled workers are not actually needed in these low-technology firms. Theoretical 
and empirical studies have shown effect of a worker's wage on productivity depends on the country of origin. Specifically, a high wage per worker is more likely to encourage the labor productivity of developed countries, whereas it reduces the labor productivity of developing and less-developed countries (Kumar 1994; Papadogonas et al. 2007; Van Dijk 2002). A possible explanation is that low-cost labor remains a competitive advantage for these countries.

Firm age shows a negative and significant sign, indicating that younger firms tend to be more dynamic, thus finding it easier to adapt to changes in the law and business environment. Meanwhile, we found the sex of the CEO or chairperson to be insignificant. It has been found that for Vietnam, capital intensity has a negative association with the performance of listed firms implying that these low-tech and labor-intensive products do not require much capital.

We continue to examine whether the correlations of various factors with performance remain consistent if data sample is split based on financial and nonfinancial status. Although the magnitude of each coefficient changes slightly, the signs are consistent except for the competition (Table 4). The competition is no longer significant if we check the financial status as well as the international trade status of firms (Table 5).

Table 4. Regression results for financial and nonfinancial firms.

\begin{tabular}{ccc}
\hline Variable & Financial (F) & Non-Financial (NF) \\
\hline "COP" & -0.187 & 0.0761 \\
& $(0.524)$ & $(0.104)$ \\
"Wage" & $-1.593^{* * *}$ & $-4.252^{* * *}$ \\
"Sex" & $(0.425)$ & $(0.355)$ \\
& -0.202 & -0.0239 \\
"Age" & $(0.504)$ & $(0.169)$ \\
& $-0.140^{* *}$ & $-0.0438^{* * *}$ \\
"CapIntensity" & $(0.0654)$ & $(0.0140)$ \\
& -0.288 & $-0.203^{* * *}$ \\
"SizeEmp" & $(0.195)$ & $(0.0643)$ \\
& 0.0904 & $0.231^{* * *}$ \\
"InterTrade" & $(0.119)$ & $(0.0346)$ \\
& 0.604 & -0.167 \\
Constant & $(0.582)$ & $(0.102)$ \\
& $20.00 * * *$ & $15.73^{* * *}$ \\
Observations & $(3.397)$ & $(0.991)$ \\
R-squared & 84 & 553 \\
\end{tabular}

Notes: ${ }^{* *}$ statistically significant at $5 \% ; * * * 1 \%$. Absolute $t$-statistics are in parentheses. For both financial and nonfinancial firms, $R$-squared equals 0.086 .

Table 5. Regression results for export-import firms.

\begin{tabular}{cccc}
\hline Variable & $\begin{array}{c}\text { International Trading } \\
\text { Firms (IT) }\end{array}$ & $\begin{array}{c}\text { Non-International } \\
\text { Trading Firms (NIT) }\end{array}$ & Both (ITNIT) \\
\hline "COP" & 0.0411 & 0.119 & 0.0830 \\
& $(0.127)$ & $(0.189)$ & $(0.106)$ \\
"Wage" & $-4.484^{* * *}$ & $-2.714^{* * *}$ & $-2.857^{* * *}$ \\
& $(0.866)$ & $(0.271)$ & $(0.258)$ \\
"Sex" & -0.227 & 0.242 & 0.00111 \\
& $(0.236)$ & $(0.224)$ & $(0.164)$ \\
"Age" & $-0.0705^{* *}$ & $-0.0528^{* * *}$ & $-0.0586^{* * *}$ \\
& $(0.0277)$ & $(0.0166)$ & $(0.0142)$ \\
& $-0.515^{* * *}$ & $-0.194^{* * *}$ & $-0.232^{* * *}$ \\
& $(0.191)$ & $(0.0666)$ & $(0.0625)$ \\
\hline
\end{tabular}


Table 5. Cont.

\begin{tabular}{cccc}
\hline Variable & $\begin{array}{c}\text { International Trading } \\
\text { Firms (IT) }\end{array}$ & $\begin{array}{c}\text { Non-International } \\
\text { Trading Firms (NIT) }\end{array}$ & Both (ITNIT) \\
\hline "SizeEmp" & $0.267^{* * *}$ & $0.207^{* * *}$ & $0.226^{* * *}$ \\
& $(0.0698)$ & $(0.0381)$ & $(0.0324)$ \\
"InterTrade" & & & -0.0852 \\
Constant & $15.25^{* * *}$ & $15.69 * * *$ & $(0.105)$ \\
Observations & $(2.025)$ & $(1.105)$ & $15.71 * *$ \\
R-squared & 137 & 500 & 637 \\
& 0.405 & 0.287 & 0.301 \\
\hline
\end{tabular}

Notes: ${ }^{* *} p<5 \% ;{ }^{* * *} p<1 \%$. Absolute $t$-statistics are in parentheses.

\subsection{Quantile Regression Results for Net Income per Employee}

We compared different quantile models by regressing net income per employee with identified explanatory variables. We applied quantile regression for quantiles smaller and larger 50th whereby $\tau$ can be identified at 25th, 50th and 75th. Table 6 reports and compares regression results of OLS and five different quantile models for small and medium sized firms. Although the signs of Competition are mixed and insignificant for the total sample at all quantiles, they are consistently and significantly positive particularly for small firms indicating that a great market share occupation of firms in small size is necessarily important to enhance their firm performance. It is noteworthy that Competition shows no significant effect if a firm's financial and international statuses are controlled (Tables 7 and 8). An important point to note is that high-wage firms are not productive compared with the low ones.

At the 75th quantile, the role of a male CEO or Chairperson is significant for small firms when the size of firms is controlled even though its impact is not straightforward. The age of firm is consistently negative, confirming the empirical strand of literature that young firms are more dynamic and adapt better with market changes. For small firms, capital intensity is negative and significant only at the 25th quantile. Consistent with the OLS regression for firm size, firm size estimate effects at different quantiles are positive to firm performance implying that firms can increase productivity by expanding their economies of scale. The magnitude of firm size effect at median is lower than that of the OLS effect. From the 25th to 90th quantile, a firm's size does not change significantly; nonetheless, at 25th quantile, it is fairly small compared with the others and is significant at $1 \%$.

Listed firms who are involved in international trade are considered to be more motivated to increase their productivity because in a broader and dynamic international market, firms need to increase productivity to exist. Literature on firms' export status and productivity confirms the causality relationship between firms' export status and their productivity and vice versa. Because the information on export status of firms is inexplicit, we created a dummy variable for firms who are involved in either export, import activities or in both export-import activities. The regression results show that only at 75th quantile for smaller firms, international trade status encourages labor productivity, whereas at the remaining quantiles, firms, international trade status has no relationship with firms' net income per employee. 
Table 6. Quantile regression results by firms' size.

\begin{tabular}{|c|c|c|c|c|c|c|c|c|c|}
\hline \multirow{2}{*}{ Variables } & $(0.25)$ & $(0.50)$ & $(0.75)$ & $(0.25)$ & $(0.50)$ & $(0.75)$ & $(0.25)$ & $(0.50)$ & $(0.75)$ \\
\hline & Small 1 & Small 2 & Small 3 & Medium 4 & Medium 5 & Medium 6 & S\&M 7 & S\&M 8 & S\&M 9 \\
\hline Competition & $\begin{array}{c}10.04^{* * *} \\
(3.789)\end{array}$ & $\begin{array}{l}8.764 * \\
(4.527)\end{array}$ & $\begin{array}{l}6.614^{* *} \\
(2.662)\end{array}$ & $\begin{array}{c}0.215 \\
(0.280)\end{array}$ & $\begin{array}{c}0.506 \\
(0.395)\end{array}$ & $\begin{array}{c}0.970 * * * \\
(0.372)\end{array}$ & $\begin{array}{c}0.0368 \\
(0.0782)\end{array}$ & $\begin{array}{c}-0.0503 \\
(0.226)\end{array}$ & $\begin{array}{c}0.230 \\
(0.373)\end{array}$ \\
\hline Wage & $\begin{array}{c}-3.649^{* * *} \\
(1.010)\end{array}$ & $\begin{array}{c}-3.164^{* * *} \\
(1.095)\end{array}$ & $\begin{array}{c}-2.549^{* *} \\
(1.230)\end{array}$ & $\begin{array}{c}-4.401 * * * \\
(0.437)\end{array}$ & $\begin{array}{c}-4.905^{* * * *} \\
(0.601)\end{array}$ & $\begin{array}{c}-5.384^{* * * *} \\
(0.590)\end{array}$ & $\begin{array}{c}-3.899^{* * *} \\
(0.473)\end{array}$ & $\begin{array}{c}-4.253^{* * *} \\
(0.665)\end{array}$ & $\begin{array}{c}-3.459^{* * *} \\
(0.812)\end{array}$ \\
\hline Sex of CEO & $\begin{array}{c}0.270 \\
(0.334)\end{array}$ & $\begin{array}{l}0.0438 \\
(0.436)\end{array}$ & $\begin{array}{c}0.822 * * \\
(0.322)\end{array}$ & $\begin{array}{l}-0.406 \\
(0.259)\end{array}$ & $\begin{array}{l}-0.272 \\
(0.174)\end{array}$ & $\begin{array}{l}-0.171 \\
(0.180)\end{array}$ & $\begin{array}{l}-0.201 \\
(0.139)\end{array}$ & $\begin{array}{c}-0.0972 \\
(0.111)\end{array}$ & $\begin{array}{c}0.139 \\
(0.276)\end{array}$ \\
\hline Age & $\begin{array}{c}-0.0596 * \\
(0.0344)\end{array}$ & $\begin{array}{c}-0.0580 \text { * } \\
(0.0328)\end{array}$ & $\begin{array}{c}-0.104^{* * *} \\
(0.0336)\end{array}$ & $\begin{array}{c}-0.00551 \\
(0.0193)\end{array}$ & $\begin{array}{l}-0.0200 \\
(0.0186)\end{array}$ & $\begin{array}{l}-0.0178 \\
(0.0108)\end{array}$ & $\begin{array}{c}-0.0377^{* *} \\
(0.0169)\end{array}$ & $\begin{array}{c}-0.0316^{*} \\
(0.0167)\end{array}$ & $\begin{array}{c}-0.0564^{* * *} \\
(0.0170)\end{array}$ \\
\hline Capital intensity & $\begin{array}{c}-0.0952 \\
(0.172)\end{array}$ & $\begin{array}{c}-0.00576 \\
(0.118)\end{array}$ & $\begin{array}{c}-0.110 \\
(0.0853)\end{array}$ & $\begin{array}{c}-0.328 \text { ** } \\
(0.148)\end{array}$ & $\begin{array}{l}-0.151 \\
(0.199)\end{array}$ & $\begin{array}{l}-0.180 \\
(0.172)\end{array}$ & $\begin{array}{l}-0.151 \\
(0.157)\end{array}$ & $\begin{array}{l}-0.146 \\
(0.103)\end{array}$ & $\begin{array}{c}-0.223^{* *} \\
(0.0879)\end{array}$ \\
\hline International trade & $\begin{array}{c}-0.0201 \\
(0.385)\end{array}$ & $\begin{array}{c}0.192 \\
(0.374)\end{array}$ & $\begin{array}{c}0.762 * * \\
(0.371)\end{array}$ & $\begin{array}{l}-0.189 \\
(0.122)\end{array}$ & $\begin{array}{c}-0.229 * \\
(0.127)\end{array}$ & $\begin{array}{l}-0.135 \\
(0.140)\end{array}$ & $\begin{array}{c}-0.170 * * \\
(0.0767)\end{array}$ & $\begin{array}{c}-0.223^{* *} \\
(0.0877)\end{array}$ & $\begin{array}{c}-0.0977 \\
(0.187)\end{array}$ \\
\hline Financial firms & $\begin{array}{l}-0.297 \\
(0.290)\end{array}$ & $\begin{array}{c}0.110 \\
(0.236)\end{array}$ & $\begin{array}{c}0.136 \\
(0.260)\end{array}$ & $\begin{array}{l}-0.348 \\
(0.226)\end{array}$ & $\begin{array}{l}-0.322 \\
(0.246)\end{array}$ & $\begin{array}{l}-0.252 \\
(0.260)\end{array}$ & $\begin{array}{c}-0.327 * * \\
(0.160)\end{array}$ & $\begin{array}{l}-0.249 \\
(0.210)\end{array}$ & $\begin{array}{c}-0.0216 \\
(0.219)\end{array}$ \\
\hline Size & & & & & & & $\begin{array}{l}0.148^{* * * *} \\
(0.0390)\end{array}$ & $\begin{array}{l}0.192 * * * \\
(0.0412)\end{array}$ & $\begin{array}{l}0.253^{* * *} \\
(0.0605)\end{array}$ \\
\hline Constant & $\begin{array}{c}20.71^{* * * *} \\
(0.766)\end{array}$ & $\begin{array}{c}21.62 * * * \\
(0.903)\end{array}$ & $\begin{array}{c}21.01^{* * *} \\
(0.677)\end{array}$ & $\begin{array}{c}21.82^{* * *} \\
(0.484)\end{array}$ & $\begin{array}{c}22.11^{* * *} \\
(0.422)\end{array}$ & $\begin{array}{c}22.35^{* * *} \\
(0.384)\end{array}$ & $\begin{array}{c}17.66^{* * * *} \\
(1.081)\end{array}$ & $\begin{array}{c}16.77^{* * * *} \\
(1.133)\end{array}$ & $\begin{array}{c}15.31^{* * * *} \\
(1.398)\end{array}$ \\
\hline Observations & 254 & 254 & 254 & 383 & 383 & 383 & 637 & 637 & 637 \\
\hline
\end{tabular}

Notes: * statistically significant at $10 \% ;{ }^{* *} 5 \% ;{ }^{* *} 1 \%$. Absolute of $t$-statistics of OLS regression are in parentheses. Coefficients and standard errors of quantile regressions are bootstrapped. Bootstrap is performed with 20 replications. 
Table 7. Quantile regression results for financial (F) and nonfinancial firms (NF).

\begin{tabular}{|c|c|c|c|c|c|c|c|c|c|}
\hline \multirow{2}{*}{ Variables } & $(0.25)$ & $(0.50)$ & $(0.75)$ & $(0.25)$ & $(0.50)$ & $(0.75)$ & $(0.25)$ & $(0.50)$ & $(0.75)$ \\
\hline & $\mathbf{F}$ & $\mathbf{F}$ & $\mathbf{F}$ & NF & NF & NF & FNF & FNF & FNF \\
\hline Competition & $\begin{array}{c}-0.0294 \\
(1.987)\end{array}$ & $\begin{array}{l}-0.393 \\
(2.378)\end{array}$ & $\begin{array}{l}-0.187 \\
(4.247)\end{array}$ & $\begin{array}{l}0.0369 \\
(0.228)\end{array}$ & $\begin{array}{c}0.173 \\
(0.282)\end{array}$ & $\begin{array}{c}0.264 \\
(0.386)\end{array}$ & $\begin{array}{l}0.0368 \\
(0.105)\end{array}$ & $\begin{array}{c}-0.0503 \\
(0.137)\end{array}$ & $\begin{array}{c}0.230 \\
(0.347)\end{array}$ \\
\hline Wage & $\begin{array}{c}-1.489^{* * * *} \\
(0.498)\end{array}$ & $\begin{array}{c}-1.482 * \\
(0.881)\end{array}$ & $\begin{array}{l}-1.827 \\
(1.189)\end{array}$ & $\begin{array}{c}-4.238^{* * *} \\
(0.536)\end{array}$ & $\begin{array}{c}-5.203^{* * *} \\
(0.467)\end{array}$ & $\begin{array}{c}-4.885^{* * *} \\
(0.512)\end{array}$ & $\begin{array}{c}-3.899 * * * \\
(0.451)\end{array}$ & $\begin{array}{c}-4.253 * * * \\
(0.905)\end{array}$ & $\begin{array}{c}-3.459^{* * *} \\
(1.181)\end{array}$ \\
\hline Sex of CEO & $\begin{array}{l}-0.148 \\
(0.444)\end{array}$ & $\begin{array}{l}-0.384 \\
(0.528)\end{array}$ & $\begin{array}{l}0.0899 \\
(0.605)\end{array}$ & $\begin{array}{l}-0.275 \\
(0.168)\end{array}$ & $\begin{array}{c}-0.0649 \\
(0.154)\end{array}$ & $\begin{array}{c}0.00667 \\
(0.222)\end{array}$ & $\begin{array}{l}-0.201 \\
(0.209)\end{array}$ & $\begin{array}{c}-0.0972 \\
(0.140)\end{array}$ & $\begin{array}{c}0.139 \\
(0.189)\end{array}$ \\
\hline Age & $\begin{array}{l}-0.0476 \\
(0.0779)\end{array}$ & $\begin{array}{c}-0.0427 \\
(0.112)\end{array}$ & $\begin{array}{c}-0.209 * * \\
(0.0986)\end{array}$ & $\begin{array}{c}-0.0369 * \\
(0.0212)\end{array}$ & $\begin{array}{c}-0.0253^{* *} \\
(0.0121)\end{array}$ & $\begin{array}{c}-0.0358 * \\
(0.0196)\end{array}$ & $\begin{array}{c}-0.0377^{* * * *} \\
(0.0139)\end{array}$ & $\begin{array}{c}-0.0316^{* * *} \\
(0.0122)\end{array}$ & $\begin{array}{c}-0.0564^{* *} \\
(0.0219)\end{array}$ \\
\hline Capital intensity & $\begin{array}{c}-0.0519 \\
(0.174)\end{array}$ & $\begin{array}{c}-0.362 * * \\
(0.142)\end{array}$ & $\begin{array}{l}-0.464 \\
(0.347)\end{array}$ & $\begin{array}{l}-0.149 \\
(0.150)\end{array}$ & $\begin{array}{l}-0.0759 \\
(0.0552)\end{array}$ & $\begin{array}{c}-0.143 \\
(0.0891)\end{array}$ & $\begin{array}{l}-0.151 \\
(0.149)\end{array}$ & $\begin{array}{l}-0.146 \\
(0.104)\end{array}$ & $\begin{array}{c}-0.223^{* *} \\
(0.0969)\end{array}$ \\
\hline International trade & $\begin{array}{c}0.105 \\
(0.184)\end{array}$ & $\begin{array}{c}0.124 \\
(0.176)\end{array}$ & $\begin{array}{l}0.0481 \\
(0.178)\end{array}$ & $\begin{array}{l}0.150^{* * *} \\
(0.0313)\end{array}$ & $\begin{array}{l}0.172 * * * \\
(0.0291)\end{array}$ & $\begin{array}{l}0.250^{* * *} \\
(0.0522)\end{array}$ & $\begin{array}{c}0.148^{* * *} \\
(0.0303)\end{array}$ & $\begin{array}{l}0.192^{* * *} \\
(0.0373)\end{array}$ & $\begin{array}{l}0.253^{* * *} \\
(0.0552)\end{array}$ \\
\hline Financial firms & $\begin{array}{c}0.372 \\
(0.754)\end{array}$ & $\begin{array}{l}0.0399 \\
(1.140)\end{array}$ & $\begin{array}{c}1.642 \\
(1.108)\end{array}$ & $\begin{array}{c}-0.188^{* *} \\
(0.0905)\end{array}$ & $\begin{array}{c}-0.209^{* * *} \\
(0.0768)\end{array}$ & $\begin{array}{c}-0.281 \text { * } \\
(0.161)\end{array}$ & $\begin{array}{l}-0.170 * \\
(0.0911)\end{array}$ & $\begin{array}{c}-0.223 \text { ** } \\
(0.0894)\end{array}$ & $\begin{array}{c}-0.0977 \\
(0.155)\end{array}$ \\
\hline Size & & & & & & & $\begin{array}{c}-0.327^{*} \\
(0.173)\end{array}$ & $\begin{array}{l}-0.249 \\
(0.188)\end{array}$ & $\begin{array}{c}-0.0216 \\
(0.229)\end{array}$ \\
\hline Constant & $\begin{array}{c}18.19^{* * *} \\
(4.934)\end{array}$ & $\begin{array}{c}19.00^{* * *} \\
(5.127)\end{array}$ & $\begin{array}{c}21.82^{* * *} \\
(5.436)\end{array}$ & $\begin{array}{c}17.78^{* * *} \\
(0.906)\end{array}$ & $\begin{array}{c}17.24^{* * *} \\
(0.921)\end{array}$ & $\begin{array}{c}15.66^{* * *} \\
(1.489)\end{array}$ & $\begin{array}{c}17.66^{* * * *} \\
(1.013)\end{array}$ & $\begin{array}{c}16.77^{* * *} \\
(1.168)\end{array}$ & $\begin{array}{c}15.31^{* * * *} \\
(1.624)\end{array}$ \\
\hline Observations & 84 & 84 & 84 & 553 & 553 & 553 & 637 & 637 & 637 \\
\hline
\end{tabular}

Notes: * statistically significant at $10 \%$; * $5 \%$; ${ }^{* * *} 1 \%$. Absolute of $t$-statistics of OLS regression are in parentheses. Coefficients and standard errors of quantile regressions are bootstrapped. Bootstrap is performed with 20 replications. 
Table 8. Quantile regression results for noninternational trading firms.

\begin{tabular}{|c|c|c|c|c|c|c|c|c|c|}
\hline \multirow{2}{*}{ Variables } & $(0.25)$ & $(0.50)$ & $(0.75)$ & $(0.25)$ & $(0.50)$ & $(0.75)$ & $(0.25)$ & $(0.50)$ & $(0.75)$ \\
\hline & IT & IT & IT & NIT & NIT & NIT & ITNIT & ITNIT & ITNIT \\
\hline \multirow[t]{2}{*}{ Competition } & 0.0392 & 0.0742 & 0.128 & 0.0446 & $-0.216^{*}$ & -0.143 & 0.0368 & -0.0503 & 0.230 \\
\hline & $(0.494)$ & $(0.608)$ & $(0.465)$ & $(0.0985)$ & (0.119) & $(0.643)$ & $(0.178)$ & $(0.244)$ & $(0.320)$ \\
\hline Wage & $\begin{array}{c}-4.232^{* * *} \\
(1.016)\end{array}$ & $\begin{array}{c}-5.559 * * * \\
(1.577)\end{array}$ & $\begin{array}{c}-4.915^{* *} \\
(1.907)\end{array}$ & $\begin{array}{c}-3.585^{* * *} \\
(0.570)\end{array}$ & $\begin{array}{c}-3.903^{* * *} \\
(0.747)\end{array}$ & $\begin{array}{c}-3.483^{* * *} \\
(1.104)\end{array}$ & $\begin{array}{c}-3.899 * * * \\
(0.424)\end{array}$ & $\begin{array}{c}-4.253 * * * \\
(0.655)\end{array}$ & $\begin{array}{c}-3.459 * * * \\
(0.873)\end{array}$ \\
\hline \multirow[t]{2}{*}{ Sex of CEO } & -0.348 & -0.323 & -0.392 & 0.0321 & 0.134 & $0.514^{*}$ & -0.201 & -0.0972 & 0.139 \\
\hline & $(0.367)$ & $(0.379)$ & $(0.250)$ & $(0.210)$ & $(0.159)$ & $(0.305)$ & $(0.153)$ & $(0.130)$ & $(0.242)$ \\
\hline \multirow[t]{2}{*}{ Age } & -0.0527 & -0.0496 & $-0.0743^{* *}$ & -0.0324 & -0.0176 & $-0.0569^{* * *}$ & $-0.0377^{* * * *}$ & $-0.0316^{* * *}$ & $-0.0564 * *$ \\
\hline & $(0.0351)$ & $(0.0371)$ & $(0.0363)$ & $(0.0201)$ & $(0.0161)$ & $(0.0215)$ & $(0.0114)$ & $(0.0118)$ & $(0.0219)$ \\
\hline \multirow[t]{2}{*}{ Capital intensity } & $-0.752 * *$ & -0.179 & -0.149 & -0.119 & $-0.169^{* *}$ & $-0.223^{*}$ & -0.151 & $-0.146^{*}$ & $-0.223^{* *}$ \\
\hline & $(0.361)$ & $(0.420)$ & $(0.320)$ & $(0.0877)$ & $(0.0815)$ & $(0.115)$ & $(0.141)$ & $(0.0878)$ & $(0.0907)$ \\
\hline \multirow[t]{2}{*}{ International trade } & 0.122 & $0.226^{*}$ & $0.325^{* *}$ & $0.143^{* * *}$ & $0.208^{* * *}$ & $0.211^{* * *}$ & $0.148^{* * *}$ & $0.192^{* * *}$ & $0.253^{* * *}$ \\
\hline & $(0.123)$ & $(0.119)$ & $(0.140)$ & $(0.0510)$ & $(0.0418)$ & $(0.0591)$ & $(0.0333)$ & $(0.0410)$ & $(0.0430)$ \\
\hline \multirow[t]{2}{*}{ Financial firms } & -0.235 & 0.150 & 1.276 & $-0.337^{*}$ & -0.256 & -0.0433 & $-0.327^{* *}$ & -0.249 & -0.0216 \\
\hline & $(1.126)$ & $(1.222)$ & (1.334) & $(0.183)$ & $(0.207)$ & $(0.138)$ & $(0.148)$ & $(0.168)$ & $(0.224)$ \\
\hline \multirow[t]{2}{*}{ Size } & & & & & & & -0.170 ** & -0.223 ** & -0.0977 \\
\hline & & & & & & & $(0.0685)$ & $(0.0977)$ & $(0.153)$ \\
\hline \multirow[t]{2}{*}{ Constant } & $18.79^{* * *}$ & $16.35^{* * *}$ & $14.38^{* * *}$ & $17.25^{* * *}$ & $15.79 * * *$ & $15.76^{* * *}$ & $17.66^{* * *}$ & $16.77^{* * *}$ & $15.31^{* * *}$ \\
\hline & (3.370) & $(3.320)$ & $(3.781)$ & $(1.393)$ & (1.177) & (1.728) & $(0.726)$ & (1.196) & (1.305) \\
\hline Observations & 137 & 137 & 137 & 500 & 500 & 500 & 637 & 637 & 637 \\
\hline
\end{tabular}

Notes: * statistically significant at $10 \%$; * $5 \%$; ${ }^{* * *} 1 \%$. Absolute of $t$-statistics of OLS regression are in parentheses. Coefficients and standard errors of quantile regressions are bootstrapped. Bootstrap is performed with 20 replications. 


\subsection{ROA and ROE as Firm Performance Measures}

The regression results for the net income per employee as a measure of firm performance has pointed out the negative association of the dependent variable with factors such as wage, age, and capital intensity. Comparing the regression results for ROA and ROE as measures of firm performance can help put these results in a broader perspective. Table 9 shows the results for the correlates of ROA for small and medium firms. The major results for ROE are summarized in the main text and the full details can be found in Appendix A.

Similar to the results for net income per employee, the OLS regression for ROA and ROE shows that capital intensity (measured by net assets divided by the number of employees) is negatively associated with firm performance $\left(\beta_{5}=-0.00621 ; p\right.$-value $\left.<0.1\right)$.

We also find that for financial firms, age and wage are negatively correlated with ROA similar to the results for net income per employee (Table 10). This is a similar pattern for net income per employee (Table 3) and ROE (the Appendix A).

Table 9. Correlates of ROA for small and medium firms.

\begin{tabular}{cccc}
\hline Variable & Small & Medium & S\&M \\
\hline "COP" & $-0.00132 * * *$ & 0.000701 & $0.000993^{*}$ \\
& $(0.000368)$ & $(0.000453)$ & $(0.000522)$ \\
"Wage" & -0.0361 & 0.0276 & -0.0184 \\
& $(0.0219)$ & $(0.0306)$ & $(0.0164)$ \\
"Sex" & 0.00416 & -0.0119 & -0.00977 \\
"Age" & $(0.0187)$ & $(0.0163)$ & $(0.0139)$ \\
& 0.000352 & -0.00246 & -0.00136 \\
"CapIntensity" & $(0.00233)$ & $(0.00159)$ & $(0.00126)$ \\
& $-0.0107 *$ & -0.00774 & $-0.00621 *$ \\
"InterTrade" & $(0.00546)$ & $(0.00503)$ & $(0.00369)$ \\
& -0.0235 & 0.00567 & 0.00487 \\
"SizeEmp" & $(0.0181)$ & $(0.00779)$ & $(0.00750)$ \\
& & & $-0.00480 *$ \\
Constant & & & $(0.00258)$ \\
Observations & $(0.0188)$ & $0.0906 * * *$ & 0.214 *** \\
R-squared & 133 & $(0.0196)$ & $(0.0728)$ \\
& 0.026 & 0.015 & 0.015 \\
\hline
\end{tabular}

Notes: ${ }^{*}$ statistically significant at $10 \% ;{ }^{* * *} 1 \%$. Absolute $t$-statistics are in parentheses.

Table 10. Correlates of ROA for financial and nonfinancial firms.

\begin{tabular}{cccc}
\hline Variable & Financial (F) & Non-Financial (NF) & Both (FNF) \\
\hline "COP" & $6.49 \times 10^{-5}$ & $0.000931^{*}$ & 0.000760 \\
& $(0.000671)$ & $(0.000562)$ & $(0.000510)$ \\
"Wage" & $-0.0122^{* *}$ & -0.0270 & -0.0182 \\
& $(0.00580)$ & $(0.0325)$ & $(0.0168)$ \\
"Sex" & 0.0172 & -0.0190 & -0.0122 \\
& $(0.0116)$ & $(0.0166)$ & $(0.0136)$ \\
"Age" & $-0.00628^{* * *}$ & -0.00155 & -0.00186 \\
& $(0.00206)$ & $(0.00138)$ & $(0.00127)$ \\
"CapIntensity" & $-0.0214^{* *}$ & -0.00425 & $-0.00734^{* *}$ \\
& $(0.00965)$ & $(0.00425)$ & $(0.00366)$ \\
"InterTrade" & 0.00742 & $-1.57 \times 10^{-6}$ & 0.000697 \\
& $(0.0149)$ & $(0.00827)$ & $(0.00788)$ \\
"SizeEmp" & 0.00424 & -0.00374 & -0.00267 \\
& $(0.00454)$ & $(0.00329)$ & $(0.00282)$ \\
"Finance" & & & $-0.0299^{* * *}$ \\
& & & $(0.00769)$ \\
Constant & -0.0551 & $0.200 * *$ & $0.1677^{* *}$ \\
Observations & $(0.122)$ & $(0.0910)$ & $(0.0768)$ \\
R-squared & 82 & 522 & 604 \\
& 0.188 & 0.013 & 0.028 \\
\hline
\end{tabular}

Notes: ${ }^{*}$ statistically significant at $10 \% ;{ }^{* *} 5 \% ; * * * 1 \%$. Absolute $t$-statistics are in parentheses. 
For a firm who engages in international trade, only competition has a significant positive correlation with ROA (Table 11) and ROE (the Appendix A). This result stands in contrary to when we regress competition with net income over employee.

Table 11. Correlates of ROA for international trading firms and noninternational-trading firms.

\begin{tabular}{cccc}
\hline Variable & $\begin{array}{c}\text { International Trading } \\
\text { Firms (IT) }\end{array}$ & $\begin{array}{c}\text { Noninternational Trading } \\
\text { Firms (NIT) }\end{array}$ & Both (ITNIT) \\
\hline "COP" & $0.00160^{* *}$ & 0.000521 & $0.000993^{*}$ \\
& $(0.000786)$ & $(0.000804)$ & $(0.000522)$ \\
"Wage" & 0.0500 & -0.0255 & -0.0184 \\
"Sex" & $(0.0837)$ & $(0.0170)$ & $(0.0164)$ \\
& -0.0341 & 0.00227 & -0.00977 \\
"Age" & $(0.0227)$ & $0.0169)$ & $(0.0139)$ \\
& 0.000136 & -0.00196 & -0.00136 \\
"CapIntensity" & $(0.00161)$ & $(0.00158)$ & $(0.00126)$ \\
& -0.000912 & $-0.00669 *$ & $-0.00629^{*}$ \\
"SizeEmp" & $(0.0117)$ & $(0.00392)$ & $(0.00369)$ \\
& -0.00803 & -0.00406 & $-0.00480 *$ \\
"InterTrade" & $(0.00562)$ & $(0.00293)$ & $(0.00258)$ \\
& & & 0.00487 \\
Constant & & & $(0.00750)$ \\
& $0.309 *$ & $0.188 * *$ & $0.214 * * *$ \\
Observations & $(0.159)$ & $(0.0825)$ & $0.0728)$ \\
R-squared & 127 & 477 & 604 \\
\hline Nots: * & 0.070 & 0.014 & 0.015 \\
\hline
\end{tabular}

Notes: ${ }^{*}$ statistically significant at $10 \% ;{ }^{* *} 5 \% ; * * * 1 \%$. Absolute $t$-statistics are in parentheses.

\section{Discussion}

\subsection{Limitations and Recommendations}

This study has several limitations. First, the study only looks at three dimensions of firm performance, namely, net income per employee, ROA and ROE. That means future studies can look at other more traditional indicators of firm performances, such as earning per share (EPS), percentage of sales from new products (Davis and Daley 2008; Vu et al. 2016), earning quality (Hoang et al. 2017), and Tobin's Q (Vu et al. 2016). Second, as this study only investigates the year 2015, it is imperative to expand the study to collect data from other years. Cross-sectional time series data would provide a more comprehensive understanding of the issue and an extension of the technical as well as theoretical contribution. For example, it is possible to probe the effectiveness of different methods in treating the endogeneity problem with the panel data (Li 2016).

In addition, this study only samples public firms; thus, it remains uncertain whether these conclusions hold for private firms. Moreover, since there are many different proxies to firm size, one can compare and contrast the empirical results when using other indicators such as total assets or total revenues. As Dang et al. (2018) have pointed out, analyses can be sensitive for different measures of firm size. Regarding the variable the sex of CEO, future studies can expand on this issue by constructing this variable differently, for example, whether a company has women on their board of directors (Carter et al. 2003; Krishnan and Park 2005; Rose 2007). As firm performance can also be influenced by various cultural factors, it is necessary for future studies to expand in this direction (Vuong et al. 2018; Vuong 2016b).

We have been particularly interested in identifying the association of competition, wage, and firm performance in Vietnam's listed firms; about $13 \%$ of the firms are operating in the financial sector and about $20 \%$ of the firms are doing international trade. Although the OLS approach enables us to examine the effects of firms' wage and competition on their performance, the quantiles regression method is also used because it yields richer characterization of the data. In this respect, we observe that firms are highly heterogeneous within a single sector. The regression results of OLS and quantiles approach show that almost all the mean and median estimates of independent variables are very 
different, except for firms' capital intensity, thus confirming our concern about the heterogeneity of firms. The magnitude of firms' capital intensity varies largely when firms' size and financial status is controlled for. Studying the correlates of firm performance is an important area for both business and government; thus, this under-researched area in Vietnam should be investigated further to prevent failures of policy and business strategy (Vuong 2018).

\subsection{Implications}

First of all, whether firm performance is measured by net income per employee, ROA, or ROE, this study consistently confirms that the sex of the CEO or chairperson is not significant in explaining firm performance. Moreover, there is a negative association between capital intensity and firm performance. As for financial firms, the age of a firm and average wage per employee are negatively associated with all types of performance indicators. When viewing all the pieces of evidence together, this study points to the fact that Vietnam's business activities are still concentrating on low labor cost, labor intensive, and low-tech production.

Considering that studies have shown that relying too much on abundant resources will be a curse as it hinders firms' ability to innovate (Vuong 2016a) and women directors having crucial role in companies where innovation is a strategic focus (Dezsö and Ross 2012), one realizes that although low cost of labor may be regarded as a competitive advantage of many sectors of Vietnam, in the age of Industry 4.0, overdependence on this factor can hamper firms' ability to adapt and thrive. Furthermore, in order for Vietnam to achieve a higher position in the global value chain and compete better in the international market, policy makers need to promote high-tech industries, which in turn encourage more highly skilled and better-paid workers.

Author Contributions: Conceptualization, T.-H.V.; methodology, T.-H.V.; software, V.-D.N.; validation, M.-T.H. and Q.-H.V.; formal analysis, T.-H.V.; investigation, V.-D.N.; resources, Q.-H.V.; data curation, V.-D.N.; writing-original draft preparation, T.-H.V.; writing-review and editing, M.-T.H.; visualization, V.-D.N.; supervision, Q.-H.V.; project administration, Q.-H.V.

Funding: This research received no external funding.

Conflicts of Interest: The authors declare no conflict of interest.

\section{Appendix A}

Table A1. Correlates of ROE for small and medium firms.

\begin{tabular}{cccc}
\hline Variable & Small & Medium & S\&M \\
\hline "COP" & 0.000752 & $0.00183 *$ & 0.00154 \\
& $(0.000691)$ & $(0.000941)$ & $(0.000941)$ \\
"Wage" & -0.0567 & 0.0175 & -0.0219 \\
& $(0.0417)$ & $(0.0641)$ & $(0.0335)$ \\
"Sex" & -0.000912 & 0.00145 & 0.00231 \\
& $(0.0346)$ & $(0.0280)$ & $(0.0238)$ \\
"Age" & -0.000208 & $-0.00460 * *$ & -0.00268 \\
& $(0.00317)$ & $(0.00226)$ & $(0.00177)$ \\
"CapIntensity" & -0.0106 & $-0.0188^{*}$ & $-0.0163 * *$ \\
& $(0.0102)$ & $(0.0108)$ & $(0.00735)$ \\
"InterTrade" & -0.0268 & 0.00264 & 0.00117 \\
& $(0.0299)$ & $(0.0144)$ & $(0.0134)$ \\
"SizeEmp" & & & 0.00337 \\
& & & $(0.00399)$ \\
Constant & $0.106 * * *$ & $0.159 * * *$ & 0.0500 \\
& $(0.0342)$ & $(0.0342)$ & $(0.114)$ \\
Observations & 133 & 471 & 604 \\
R-squared & 0.013 & 0.017 & 0.013 \\
\hline
\end{tabular}

Notes: ${ }^{*}$ significant at $10 \% ;{ }^{* *} 5 \% ; * * * 1 \%$. Absolute $t$-statistics are in parentheses. 
Table A2. Correlates of ROE for financial and nonfinancial firms.

\begin{tabular}{cccc}
\hline Variable & Financial (F) & Nonfinancial (NF) & Both (FNF) \\
\hline "COP" & -0.00112 & 0.00137 & 0.00105 \\
& $(0.00125)$ & $(0.000973)$ & $(0.000900)$ \\
"Wage" & $-0.0162^{*}$ & -0.0281 & -0.0214 \\
& $(0.00937)$ & $(0.0647)$ & $(0.0323)$ \\
"Sex" & $0.0351^{*}$ & -0.0132 & -0.00266 \\
& $(0.0203)$ & $(0.0283)$ & $(0.0232)$ \\
"Age" & $-0.00849^{* *}$ & $-0.00340^{*}$ & $-0.00374^{* *}$ \\
& $(0.00337)$ & $(0.00195)$ & $(0.00180)$ \\
"CapIntensity" & $-0.0308^{* *}$ & $-0.0160^{*}$ & $-0.0187^{* *}$ \\
& $(0.0142)$ & $(0.00827)$ & $(0.00726)$ \\
"InterTrade" & -0.00794 & -0.00835 & -0.00749 \\
& $(0.0365)$ & $(0.0146)$ & $(0.0139)$ \\
"SizeEmp" & $0.0177^{*}$ & 0.00656 & $0.00779 *$ \\
& $(0.00935)$ & $(0.00482)$ & $(0.00424)$ \\
"Finance" & & & $-0.0620^{* * *}$ \\
& & & $(0.0137)$ \\
Constant & -0.389 & -0.00684 & -0.0472 \\
& $(0.250)$ & $(0.136)$ & $(0.117)$ \\
Observations & 82 & 522 & 604 \\
R-squared & 0.124 & 0.017 & 0.031 \\
\hline
\end{tabular}

Notes: ${ }^{*}$ significant at $10 \%$; ${ }^{* *} 5 \% ;{ }^{* * *} 1 \%$. Absolute $t$-statistics are in parentheses.

Table A3. Correlates of ROE for international trading firms and non-international-trading firms.

\begin{tabular}{cccc}
\hline Variable & $\begin{array}{c}\text { International Trading } \\
\text { Firms (IT) }\end{array}$ & $\begin{array}{c}\text { Noninternational } \\
\text { Trading Firms (NIT) }\end{array}$ & Both (ITNIT) \\
\hline "COP" & $0.00189 * *$ & 0.00170 & 0.00154 \\
"Wage" & $(0.000768)$ & $(0.00187)$ & $(0.000940)$ \\
& 0.00738 & -0.0239 & -0.0219 \\
"Sex" & $(0.167)$ & $(0.0335)$ & $(0.0335)$ \\
& -0.0185 & 0.0103 & 0.00210 \\
"Age" & $(0.0353)$ & $(0.0322)$ & $(0.0236)$ \\
& -0.00123 & -0.00317 & -0.00265 \\
"CapIntensity" & $(0.00307)$ & $(0.00215)$ & $(0.00177)$ \\
& -0.00145 & $-0.0176 * *$ & $-0.0164 *$ \\
"SizeEmp" & $(0.0282)$ & $(0.00762)$ & $0.00729)$ \\
& -0.00526 & 0.00487 & 0.00341 \\
"InterTrade" & $(0.00934)$ & $(0.00453)$ & $0.00396)$ \\
& 0.289 & 0.00530 & 0.0491 \\
Constant & $(0.266)$ & $(0.128)$ & $(0.113)$ \\
& 127 & 477 & 604 \\
Observations & 0.017 & 0.015 & 0.013 \\
R-squared & $0.00189 * *$ & 0.00170 & 0.00154 \\
& $(0.000768)$ & $(0.00187)$ & $(0.000940)$ \\
\hline
\end{tabular}

Notes: ${ }^{* *}$ significant at $5 \%$; Absolute $t$-statistics are in parentheses.

\section{References}

Andersson, Martin, Sara Johansson, and Hans Lööf. 2012. Firm performance and international trade-evidence from a small open economy. In The Regional Economics of Knowledge and Talent: Local Advantage in a Global Context. Edited by Charlie Karlsson, Borje Johanson and Roger. R. Stough. Glos: Edward Elgar Publishing, pp. 320-42.

Baum, C. 2013. Quantile Regression, Lecture Notes for Applied Econometrics. Available online: http://fmwww.bc. edu/EC-C/S2013/823/EC823.S2013.nn04.slides.pdf (accessed on 17 March 2019). 
Boardman, Anthony E., Claude Laurin, Mark A. Moore, and Aidan R. Vining. 2013. Efficiency, profitability and welfare gains from the Canadian National Railway privatization. Research in Transportation Business $\mathcal{E}$ Management 6: 19-30.

Bourlès, Renaud, Gilbert Cette, Jimmy Lopez, Jacques Mairesse, and Giuseppe Nicoletti. 2013. Do product market regulations in upstream sectors curb productivity growth? Panel data evidence for OECD countries. Review of Economics and Statistics 95: 1750-68. [CrossRef]

Brandt, Loren, Johannes Van Biesebroeck, and Yifan Zhang. 2012. Creative accounting or creative destruction? Firm-level productivity growth in Chinese manufacturing. Journal of Development Economics 97: 339-51. [CrossRef]

Brennan, Niamh M., and Jacqueline McCafferty. 1997. Corporate governance practices in Irish companies. IBAR-Irish Business and Administrative Research 18: 116-35.

Camisón, César, and Ana Villar-López. 2014. Organizational innovation as an enabler of technological innovation capabilities and firm performance. Journal of Business Research 67: 2891-902. [CrossRef]

Carter, David A., Betty J. Simkins, and W. Gary Simpson. 2003. Corporate Governance, Board Diversity, and Firm Value. Financial Review 38: 33-53. [CrossRef]

Choudhary, Amod. 2014. Smartphones and their impact on net income per employee for selected U.S. firms. Review of Business \& Finance Studies 5: 6-17.

Coles, Jeffrey L., Zhichuan Li, and Albert Y. Wang. 2017. Industry tournament incentives. The Review of Financial Studies 31: 1418-59. [CrossRef]

Core, John, and Wayne Guay. 1999. The use of equity grants to manage optimal equity incentive levels. Journal of Accounting and Economics 28: 151-84. [CrossRef]

Dang, Chongyu, Zhichuan Frank Li, and Chen Yang. 2018. Measuring firm size in empirical corporate finance. Journal of Banking \& Finance 86: 159-76.

Davis, Deborah, and Barbara J. Daley. 2008. The learning organization and its dimensions as key factors in firms' performance. Human Resource Development International 11: 51-66. [CrossRef]

De Loecker, Jan, and Jan Van Biesebroeck. 2018. Effect of international competition on firm productivity and market power. In The Oxford Handbook of Productivity Analysis. Edited by Emili Grifell-Tatjé, Knox C. A. Lovell and Robin C. Sickles. New York: Oxford University Press, p. 463.

Dezsö, Cristian L., and David Gaddis Ross. 2012. Does female representation in top management improve firm performance? A panel data investigation. Strategic Management Journal 33: 1072-89. [CrossRef]

Doğan, Mesut. 2013. Does firm size affect the firm profitability? Evidence from Turkey. Research Journal of Finance and Accounting 4: 53-59.

Garicano, Luis, Claire Lelarge, and John Van Reenen. 2016. Firm size distortions and the productivity distribution: Evidence from france. American Economic Review 106: 3439-79. [CrossRef]

Garicano, Luis, Claire Lelarge, and John Van Reenen. 2017. Size-Based Regulations and Firm Growth: Is Small Beautiful? Paris: Rue de la Banque, Banque de France.

GERA. 2018. Global Entrepreneurship Monitor 2017/2018 Global Report. Babson Park: Global Entrepreneurship Research Association, Available online: https://www.gemconsortium.org/report/50012 (accessed on 11 April 2019).

Giroud, Xavier, and Holger M. Mueller. 2011. Corporate governance, product market competition, and equity prices. The Journal of Finance 66: 563-600. [CrossRef]

Hoang, Trang Cam, Indra Abeysekera, and Shiguang Ma. 2017. The effect of board diversity on earnings quality: An empirical study of listed firms in Vietnam. Australian Accounting Review 27: 146-63. [CrossRef]

Honoré, Bo E. 1992. Trimmed LAD and least squares estimation of truncated and censored regression models with fixed effects. Econometrica 60: 533-65. [CrossRef]

Kopf, Dan. 2018. Vietnam Is the Most Globalized Populous Country in Modern History. Available online: https://www.weforum.org/agenda/2018/10/vietnam-is-the-most-globalized-populous-country-inmodern-history/ (accessed on 17 March 2019).

Krishnan, Hema A., and Daewoo Park. 2005. A few good women: On top management teams. Journal of Business Research 58: 1712-20. [CrossRef]

Kumar, Nagesh. 1994. Determinants of export orientation of foreign production by US multinationals: An inter-country analysis. Journal of International Business Studies 25: 141-56. [CrossRef] 
Kurshev, Alexander, and Ilya A. Strebulaev. 2015. Firm size and capital structure. Quarterly Journal of Finance 5: 1550008. [CrossRef]

Le, Thi Phuong Vy, and Thi Bich Nguyet Phan. 2017. Capital structure and firm performance: Empirical evidence from a small transition country. Research in International Business and Finance 42: 710-26. [CrossRef]

Li, Zhichuan Frank. 2014. Mutual monitoring and corporate governance. Journal of Banking E Finance 45: 255-69.

Li, Zhichuan Frank. 2016. Endogeneity in CEO power: A survey and experiment. Investment Analysts Journal 45: 149-62. [CrossRef]

Liu, Yu, Zuobao Wei, and Feixue Xie. 2014. Do women directors improve firm performance in China? Journal of Corporate Finance 28: 169-84. [CrossRef]

Lückerath-Rovers, Mijntje. 2013. Women on boards and firm performance. Journal of Management E Governance 17: 491-509.

Munch, Jakob, and Georg Schaur. 2018. The effect of export promotion on firm-level performance. American Economic Journal: Economic Policy 10: 357-87. [CrossRef]

Nguyen, Bich Thi Ngoc, Hai Thi Thanh Tran, Oanh Hoang Le, Phuoc Thi Nguyen, Thien Hiep Trinh, and Viet Le. 2015. Association between corporate social responsibility disclosures and firm value-Empirical evidence from Vietnam. International Journal of Accounting and Financial Reporting 5: 212-28. [CrossRef]

Nhan Dan. 2017. Enhancing Role of Vietnamese Entrepreneurs in New Stage of Development. Available online: http://en.nhandan.org.vn/business/item/5566302-enhancing-role-of-vietnamese-entrepreneurs-innew-stage-of-development.html (accessed on 14 February 2019).

Nickell, Stephen J. 1996. Competition and corporate performance. Journal of Political Economy 104: 724-46. [CrossRef]

Orlitzky, Marc. 2001. Does Firm Size Comfound the Relationship Between Corporate Social Performance and Firm Financial Performance? Journal of Business Ethics 33: 167-80. [CrossRef]

Schiffbauer, Marc, and Sandra Ospina. 2006. Competition and Firm Productivity: Evidence from Firm-Level Data. IMF Working Paper. Washington: International Monetary Fund.

Papadogonas, Theodore, Fotini Voulgaris, and George Agiomirgianakis. 2007. Determinants of export behavior in the Greek manufacturing sector. Operational Research 7: 121-35. [CrossRef]

Pham, Minh Chinh, and Quan Hoang Vuong. 2009. Kinh te Vietnam: Thang tram va Dot Pha [Vietnam's Economy: Vissicitude and Breakthrough]. Hanoi: NXB Tri thuc.

Phung, Duc Nam, and Thi Phuong Thao Hoang. 2013. Corporate ownership and firm performance in emerging market: A study of Vietnamese listed firms. Paper presented at World Business and Social Science Research Conference, Bangkok, Thailand, December 18-19.

Phung, Duc Nam, and Thi Phuong Vy Le. 2013. Foreign Ownership, Capital Structure and Firm Performance: Empirical Evidence from Vietnamese Listed Firms. The IUP Journal of Corporate Governance 12: 40-58.

Phung, Duc Nam, and Anil V. Mishra. 2016. Ownership structure and firm performance: Evidence from Vietnamese listed firms. Australian Economic Papers 55: 63-98. [CrossRef]

Piget, Patrick, and Mohamed Kossaï. 2013. The Relationship between Information and Communication Technology Use and Firm Performance in Developing Countries: A Case Study of Electrical and Electronic Goods Manufacturing SMEs in Tunisia. African Development Review 25: 330-43. [CrossRef]

Rose, Caspar. 2007. Does female board representation influence firm performance? The Danish evidence. Corporate Governance: An International Review 15: 404-13. [CrossRef]

Schreck, Philipp, and Sascha Raithel. 2015. Corporate social performance, firm size, and organizational visibility: Distinct and joint effects on voluntary sustainability reporting. Business $\mathcal{E}$ Society 57: 742-78.

Silva, Armando, Oscar Afonso, and Ana Paula Africano. 2013. Economic performance and international trade engagement: the case of Portuguese manufacturing firms. International Economics and Economic Policy 10: 521-47. [CrossRef]

Sun, Li, and T. Robert Yu. 2015. The impact of corporate social responsibility on employee performance and cost. Review of Accounting and Finance 14: 262-84. [CrossRef]

Swierczek, Fredric William, and Thai Thanh Ha. 2003. Entrepreneurial Orientation, Uncertainty Avoidance and Firm Performance: An Analysis of Thai and Vietnamese SMEs. The International Journal of Entrepreneurship and Innovation 4: 46-58. [CrossRef]

Tran, Ngo My, Walter Nonneman, and Ann Jorissen. 2014. Government ownership and firm performance: The case of Vietnam. International Journal of Economics and Financial Issues 4: 628-50. 
Truong, Dong Loc, Ger Lanjouw, and Robert Lensink. 2006. The impact of privatization on firm performance in a transition economy: The case of Vietnam. Economics of Transition 14: 349-89.

Van Dijk, Michiel. 2002. The Determinants of Export Performance in Developing Countries: The Case of Indonesian Manufacturing. Eindhoven: Eindhoven Centre for Innovation Studies.

Vo, Duc Hong, and Tri Minh Nguyen. 2014. The impact of corporate governance on firm performance: Empirical study in Vietnam. International Journal of Economics and Finance 6: 1-13. [CrossRef]

Thanh, Vu Huu, and Nguyen Minh Ha. 2013. The effect of banking relationship on firm performance in Vietnam. International Journal of Economics and Finance 5: 148-58. [CrossRef]

$\mathrm{Vu}$, Van Huong, Quang Tuyen Tran, Van Tuan Nguyen, and Steven Lim. 2016. Corruption, types of corruption and firm financial performance: New evidence from a transitional economy. Journal of Business Ethics 148: 847-58.

Vuong, Quan-Hoang. 2016a. Determinants of firm performance in a less innovative transition system: exploring Vietnamese longitudinal data. International Journal of Transitions and Innovation Systems 5: 20-45. [CrossRef]

Vuong, Quan-Hoang. 2016b. Impacts of geographical locations and sociocultural traits on the Vietnamese entrepreneurship. SpringerPlus 5: 1189. [CrossRef]

Vuong, Quan-Hoang. 2018. The (ir)rational consideration of the cost of science in transition economies. Nature Human Behaviour 2: 5. [CrossRef]

Vuong, Quan-Hoang. 2019a. Computational entrepreneurship: From economic complexities to interdisciplinary research. Problems and Perspectives in Management 17: 117-29. [CrossRef]

Vuong, Quan-Hoang. 2019b. The financial economy of Viet Nam in an age of reform, 1986-2016. In Routledge Handbook of Banking and Finance in Asia. Edited by Ulrich Volz, Peter J. Morgan and Naoyuki Yoshino. London: Routledge (T\&F), pp. 201-22.

Vuong, Quan Hoang, and Tri Dung Tran. 2009. The cultural dimensions of the Vietnamese private entrepreneurship. IUP Journal of Entrepreneurship Development VI: 54-78. [CrossRef]

Vuong, Quan-Hoang, Quang-Khiem Bui, Viet-Phuong La, Thu-Trang Vuong, Viet-Ha T. Nguyen, Manh-Toan Ho, Hong-Kong T. Nguyen, and Manh-Tung Ho. 2018. Cultural additivity: behavioural insights from the interaction of Confucianism, Buddhism and Taoism in folktales. Palgrave Communications 4: 143. [CrossRef]

Vuong, Quan-Hoang, Manh-Tung Ho, Thu-Trang Vuong, Viet-Phuong La, Manh-Toan Ho, Kien-Cuong P. Nghiem, Bach Xuan Tran, Hai-Ha Giang, Thu-Vu Giang, Carl Latkin, and et al. 2019. Artificial Intelligence vs. Natural Stupidity: Evaluating AI Readiness for the Vietnamese Medical Information System. Journal of Clinical Medicine 8: 168. [CrossRef]

Wagner, Joachim. 2012. International trade and firm performance: A survey of empirical studies since 2006. Review of World Economics 148: 235-67. [CrossRef]

Wang, Zhining, and Nianxin Wang. 2012. Knowledge sharing, innovation and firm performance. Expert Systems with Applications 39: 8899-908. [CrossRef]

Wolff, James A., and Timothy L. Pett. 2000. Internationalization of small firms: An examination of export competitive patterns, firm size, and export performance. Journal of Small Business Management 38: 34.

Zhang, Guoqiang Peter, and Yusen Xia. 2013. Does quality still pay? A reexamination of the relationship between effective quality management and firm performance. Production and Operations Management 22: 120-36. [CrossRef]

(C) 2019 by the authors. Licensee MDPI, Basel, Switzerland. This article is an open access article distributed under the terms and conditions of the Creative Commons Attribution (CC BY) license (http://creativecommons.org/licenses/by/4.0/). 